\title{
Discussions de la 1ère partie
}

\section{(2) OpenEdition}

1 Journals

Édition électronique

URL : https://journals.openedition.org/tc/611

DOI : $10.4000 /$ tc. 611

ISSN : 1952-420X

Éditeur

Éditions de l'EHESS

Édition imprimée

Date de publication : 1 septembre 1994

ISSN : 0248-6016

Référence électronique

«Discussions de la 1ère partie », Techniques \& Culture [En ligne], 21 | 1994, mis en ligne le 30 décembre 2005, consulté le 29 septembre 2022. URL : http://journals.openedition.org/tc/611 ; DOI : https:// doi.org/10.4000/tc.611

Ce document a été généré automatiquement le 29 septembre 2022.

Tous droits réservés 
Discussions de la 1ère partie 